\title{
Mashare - Climate
}

Mashare is located after the confluence of the Cuito and Cubango Rivers at the Angolan-Namibian border and has an altitude of $1,068 \mathrm{~m}$. The climate at this site is characterized by semi-arid conditions with a rainy season during the austral summer and a dry period from May to September (Fig. 1). During the period 1971 to 2000 , the annual mean rainfall was determined to be $571 \mathrm{~mm}$ (Tab. 1). Over the period 1950 to 2009 , the annual rainfall in Mashare shows a high interannual variability without any obvious trend (Fig. 2). Mashare has an annual mean temperature of $22.3{ }^{\circ} \mathrm{C}$ with October and July being the hottest and the coldest months with average mean temperature of
$26.2{ }^{\circ} \mathrm{C}$ and $16.2{ }^{\circ} \mathrm{C}$ respectively. The long-term annual mean temperature shows a moderate interannual variability with an increase in temperature since the

Table 1: General information and key figures.

\begin{tabular}{|l|l|}
\hline Climate & Time period \\
\hline semi-arid & $1971-2000$ \\
\hline Annual mean temperature & Mean diurnal temperature range \\
\hline $22.3^{\circ} \mathrm{C}$ & $15.9^{\circ} \mathrm{C}$ \\
\hline Mean number of frost days per year & Annual mean rainfall \\
\hline 21 & $571 \mathrm{~mm}$ \\
\hline Dry season & Vegetation period \\
\hline May to September & November to March \\
\hline
\end{tabular}

late 1970s (Fig. 3). On average 21 frost days per year were recorded in the dry season from May to September.

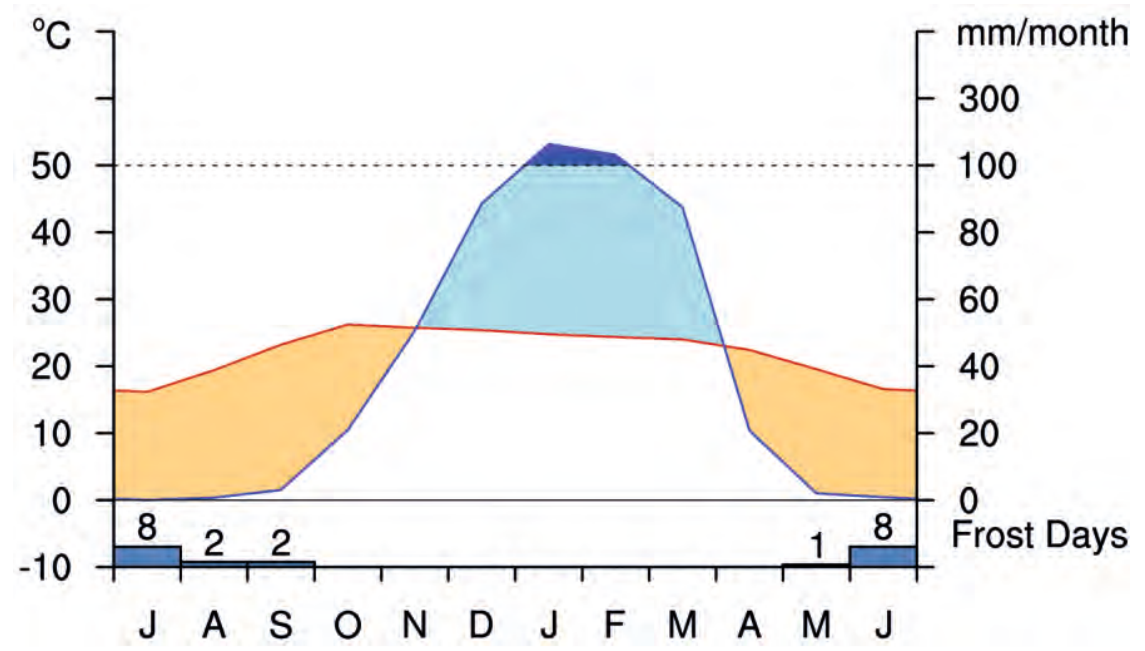

Fig. 1: Walter-Lieth climate diagram of Mashare (data source: Temperature from the Climatic Research Unit (CRU), rainfall from the Global Precipitation Climatology Centre (GPCC)).

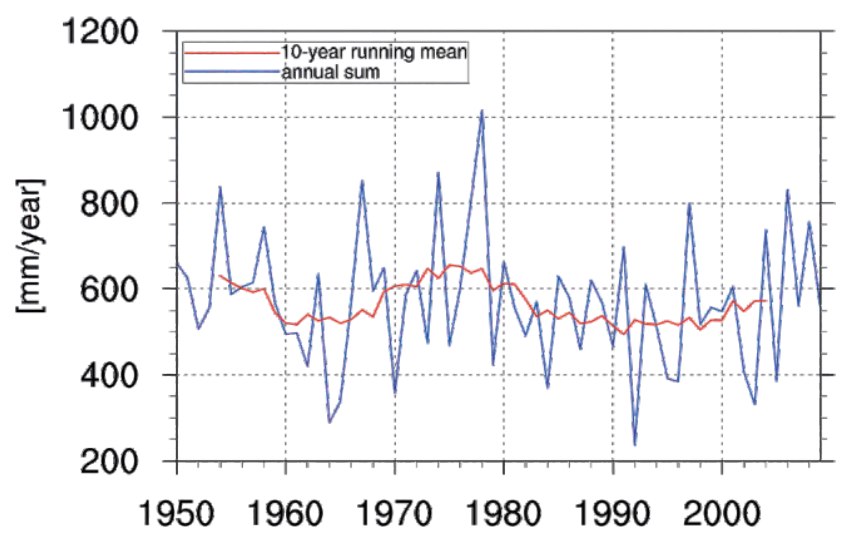

Fig. 2: Annual sum of rainfall in Mashare between 1950 and 2009 (data source: Global Precipitation Climatology Centre (GPCC)). 


\section{Acknowledgements}

This study was funded by the BMBF (The Future Okavango project). For details see authors' general acknowledgements in this volume.

\section{Data source}

Temperature data, frost days, diurnal temperature range were taken from the Climatic Research Unit (CRU) (Mitchell \& Jones 2005). Rainfall data were taken from the Global Precipitation Climatology Centre (GPCC) (Becker et al. 2013). Both gridded observational data sets have a horizontal resolution of $0.5^{\circ} \times 0.5^{\circ}$ (about $55 \mathrm{~km} \times 55 \mathrm{~km}$ ). Altitude was taken from the NASA Shuttle Radar Topographic Mission (SRTM) 90 m Digital Elevation Database, (Jarvis, A., Reuter, H. I., Nelson, A., Guevara, E., (2008): Hole-filled SRTM for the globe Version 4, available from the CGIAR-CSI SRTM $90 \mathrm{~m}$ Database (http://srtm.csi.cgiar.org)).

\section{References}

Becker, A., Finger, P., Meyer-Christoffer, A., Rudolf, B., Schamm, K., Schneider, U., and Ziese, M. (2013): A description of the global land-surface precipitation data products of the Global Precipitation Climatology Centre with sample applications including centennial (trend) analysis from 1901-present. - Earth System Science Data 5: 71-99. CrossRef

Mitchell, T.D., Jones, P.D. (2005): An improved method of constructing a database of monthly climate observations and associated highresolution grids. - International Journal of Climatology 25: 693-712. CrossRef 